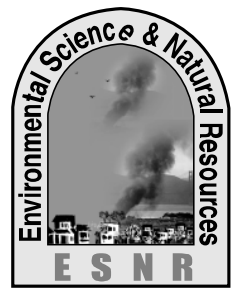

J. Environ. Sci. \& Natural Resources, 7(1): 157- 167, 2014

ISSN 1999-7361

\title{
Physico-chemical Properties of Effluents Discharged from Different Industries of Gazipur, Bangladesh and its Suitability for Agricultural \\ Land
}

\author{
M. Rana ${ }^{1}$, B. Bakali ${ }^{1}$, M. Y. Mia ${ }^{1 *}$ and M. Z. Hossen ${ }^{1}$ \\ ${ }^{1}$ Department of Environmental Science and Resource Management \\ Mawlana Bhashani Science and Technology University, Tangail-1902, Bangladesh \\ ${ }^{2}$ Department of Agri-chemistry, Bangladesh Agricultural University, Mymensingh \\ *Corresponding author: oshin1998@yahoo.com
}

\begin{abstract}
The study was conducted to assess physical parameters, major ionic constituents and trace metals content at Gazipur area to know the quality of effluent during March in 2013 for irrigation usage. The $\mathrm{pH}$ of collected effluent samples were almost neutral but in case of TDS values all the samples were suitable for irrigation where considering EC values almost harmful for irrigation. The anion i.e. in case of $\mathrm{CO}_{3}, \mathrm{SO}_{4}$ and $\mathrm{PO}_{4}$ all the collected effluent samples were suitable for irrigation but in case of almost $\mathrm{Cl}$ values and all $\mathrm{HCO}_{3}$ values unsuitable for irrigation. Similarly, the cation i.e. in case of $\mathrm{Na}, \mathrm{Mg}, \mathrm{Ca}$ and $\mathrm{K}$ all the collected effluent samples were suitable for irrigation. Among the studied trace metals ( $\mathrm{Fe}, \mathrm{Zn}, \mathrm{Cu}, \mathrm{Pb}, \mathrm{Cd}$ and $\mathrm{Mn}$ ) all of the collected effluent samples were suitable for irrigation except two samples for $\mathrm{Mn}$ and $\mathrm{Cu}$. On the other hand, in case of SAR most of the samples were excellent category but in case of SSP most of the samples were graded as doubtful and in case of RSC and hardness most of the samples were unsuitable class for irrigation purposes. So to protect the agricultural land whole of the study area a pollution free technology such as Effluent Treatment Plants (ETP) to each industry should be established.
\end{abstract}

Key Words: Industrialization, Effluent, Trace metals and Water pollution

\section{Introduction}

Bangladesh lies in the northeastern part of South Asia between $20^{\circ} 34^{\prime}$ to $26^{\circ} 38^{\prime}$ North latitude and $88^{\circ} 01^{\prime}$ to $92^{\circ} 41$ East latitude. It is one of the least developed countries with a low resources base under high population pressure, a low land man ratio. More than 124 million people live in the country of $147570 \mathrm{sq}$. $\mathrm{km}$ area. Rapid population growth increasing poverty, unemployment and scarce of natural resources leading the country to least developed. The vast majority of the population depends on natural resources. However, most of the resources are overexploited. This is causing environmental deprivation in the way of at present day's unplanned industrialization and urbanization, vehicular pollution, deforestation, unsustainable agriculture practices etc. They offer the alteration of physical, chemical and biological properties of air, water and soil counting change in temperature, odor, noise, turbidity, ray and to the original properties that is harmful to public health, livestock, wildlife, fish and other biodiversity (Huq et al., 1993; Mohammad et al., 2011).

The industrial areas in Bangladesh are situated in the middle part of densely populated regions and the growth of industries has generally been unplanned without keeping the issue of environmental protection in careful consideration. Gazipur District is one such industrial cluster where rapid, unplanned industrial expansion has led to serious local pollution. This area was historically important rice growing area but its close proximity to Dhaka has gradually led to more industries locating there over the past 15 years. There are now several types of industry in the area including tannery, poultry farms and pharmaceutical industries but it is dominated by textile manufacturers, including dyeing and printing units. There are so many industries in Gazipur, only a few of them have installed effluent treatment plant (ETP). Indiscriminate discharges of liquid waste by the industries in and around Gazipur industrial has ruined a large part of the Turag River and Baimail jheel causing immense sufferings to residents living on the banks as well as surrounding agricultural land (Rashid, 2012).

Local peoples say bricks kilns have left their fruit trees unproductive, while industrial waste exterminated fish in the river and nearby water bodies, increased mosquitoes and made cropland infertile. Bangladesh Small and Cottage Industrial Corporation (BSCIC) were established at Konabari in 1980 by the Bangladesh Government to promote and expand small and cottage industries. Since then the industries are polluting surrounding environment despite getting different facility packages from the government. Recently, the BSCIC authority have made a list of 152 polluting industries that include 56 dyeing and textile industries, 50 chemical and 
pharmaceuticals, 9 food processing industries and other 37 engineering industries. None of these industries has installed an effluent treatment plant (ETP). The BSCIC provided to the entrepreneur in a subsidized price along with many other facilities, but most of the industries are paying back by polluting the environment. The industry waste has spoiled everything (CNN Report, 2012).

Keeping all this views in mind an experiment was set up to assess the physico-chemical properties of the effluents such as $\mathrm{pH}$, DO, TDS, EC, chloride, phosphate, sulphate, calcium, magnesium, carbonate, bicarbonate, sodium and pottasium discharged from different industries, to determine the status of trace metals ( $\mathrm{Fe}, \mathrm{Cd}, \mathrm{Pb}, \mathrm{Cu}, \mathrm{Zn}, \mathrm{Mn}$ ) concentration of the effluent discharged from different industries and to assess the suitability of the effluents as irrigation water.

\section{Materials and Methods}

A total of 26 effluent samples were collected from Chandra to Baimail beside the Chandra-Gazipur Chourasta highway road at the outlet of different industries under the Gazipur districts during March in 2013 following the sampling techniques as outlined by APHA (1995) and Sincero and Sincero (2004) shown in Table 1. Each effluent samples were collected in $500 \mathrm{ml}$ narrow-mouth high density polyethylene bottles. Each bottle were cleaned in the laboratory with dilute $\mathrm{HCl}(1: 1)$ and then rinsed twice with distilled water. Before sampling, bottles were also rinsed with the sampled effluent. After sampling, the bottles containing samples were sealed immediately to avoid exposure to air and marked with necessary information. Then all the effluent samples were analysed for $\mathrm{pH}, \mathrm{EC}$, TDS and DO at the laboratory of Department of Environmental Science and Resource Management (ESRM), Mawlana Bhashani Science and Technology University (MBSTU), Tangail. The samples for the analysis of trace metals were carefully filtered through Whatman filter paper no. 42 to remove undesirable solid and suspended materials. After filtration $150 \mathrm{ml}$ of each sample was taken and a few drops of concentrated $\mathrm{HNO}_{3}$ (extra-pure) was added into the samples and then kept in the freeze for further analysis. Then the samples were taken to the Department of Agricultural Chemistry, Bangladesh Agricultural University (BAU), Mymensingh for analyzed major cations (Ca, $\mathrm{Mg}, \mathrm{Na}$ and $\mathrm{K})$, major anions $\left(\mathrm{Cl}, \mathrm{HCO}_{3}, \mathrm{CO}_{3}, \mathrm{SO}_{4}\right.$ and $\left.\mathrm{PO}_{4}\right)$ and trace metals $(\mathrm{Fe}, \mathrm{Mn}, \mathrm{Zn}, \mathrm{Pb}, \mathrm{Cd}$ and $\mathrm{Mn}$ ) following standard analytical methods. Calcium and magnesium were determined titrimetrically using standard $\mathrm{Na}_{2}$ EDTA. Chloride was measured by titrimetrically using standard $\mathrm{AgNO}_{3}$ solution.
Carbonate and bicarbonate were also determined by titrimetrically using standard $\mathrm{H}_{2} \mathrm{SO}_{4}$ solution. Sodium and potassium were measured by flame photometrically whereas sulphate and phosphate were determined by spectrophotometrically. The concentrations of $\mathrm{Fe}, \mathrm{Mn}, \mathrm{Zn}, \mathrm{Pb}, \mathrm{Cd}$ and $\mathrm{Cu}$ in effluent samples were analyzed by atomic absorption spectrophotometer by using single hallow cathode lamp at the wavelengths of 248.3, 279.5, 213.9, 283.3, 228.8 and $324.7 \mathrm{~nm}$, respectively following the procedure as described by APHA (1995). The parameters such as sodium adsorption ratio (SAR), soluble sodium percent (SSP), residual sodium carbonate (RSC), permeability index (PI) and hardness $\left(\mathrm{H}_{\mathrm{T}}\right)$ were calculated to evaluate the suitability of the effluent quality for agricultural purposes. Further the results of the analyses were interpreted using graphical representations like SAR vs salinity hazard as described by Richards (1968) and Doneen plot (1964).

\section{Results and Discussions}

The results of the analysis of effluents samples collected from different industrial outlet are given in Table $2 \& 3$. Figure 1 shows the percent contribution of individual ions towards the total cationic and anionic mass balance.

\section{a) Physicochemical properties of effluent}

The $\mathrm{pH}$ of collected effluent samples were fluctuated between 6.05 to 7.28 with a mean value of 6.64 $(\mathrm{SD} \pm 0.35)$ indicating little acidity to alkaline of water (Table 2). These might be due to the presence of ions such as $\mathrm{Ca}, \mathrm{Mg}$ and $\mathrm{Na}$ in water (Rao et al., 1982). According to Ayers and Westcot (1985), the acceptable range of $\mathrm{pH}$ for irrigation water is 6.5 to 8.4. On the basis of measured $\mathrm{pH}$ of all collected effluent samples were not problematic for long-term irrigation. The EC of all collected effluent samples were within the range of 181 to $1995 \mu \mathrm{S} \mathrm{cm}^{-1}$ with an average value of $1337.35 \mu \mathrm{S} \mathrm{cm} \mathrm{cm}^{-1}(\mathrm{SD} \pm 494.50)$ (Table 2). According to Richards (1968), samples under test were rated in the category $\mathrm{C} 1(\mathrm{EC}<250$ $\left.\mu \mathrm{Scm}^{-1}\right), \mathrm{C} 2\left(\mathrm{EC}=250-750 \mu \mathrm{Scm}^{-1}\right)$ and $\mathrm{C} 3(\mathrm{EC}=$ 751-2250 $\mu \mathrm{S} \mathrm{cm}^{-1}$ ) indicating low to high salinity. Medium salinity class water might be applied with moderate leaching. High salinity class of water was treated as unsuitable for irrigation purpose (Agarwal et al., 1982). On the basis of measured EC most of the collected effluent samples were problematic for longterm irrigation. A similar observation was reported by Singh et al. (2010) for waste water of Raniganj industrial area in India. 
Table 1: Detailed information regarding effluents sampling sites at the major polluting industrial areas of Gazipur, Bangladesh

\begin{tabular}{|c|c|c|}
\hline Sample ID. & Name of the industry & Sampling area \\
\hline 01 & Moizuddin Knitwaer Limited & Bimail (Konabari) \\
\hline 02 & Delta Composite Textile Limited & Sofipur \\
\hline 03 & General Pharmaceuticals Ltd. & Mouchak \\
\hline 04 & Beximco Pharmaceuticals & Mouchak \\
\hline 05 & Zaber and Zubuaer Fabrics limited & Bimail (Konabari) \\
\hline 06 & Hydroxide Knitwear Limited & Mouchak \\
\hline 07 & Amco Drugs Industries & BSCIC (Konabari) \\
\hline 08 & Cotton Club Limited & Zurun (Konabari) \\
\hline 09 & Purbani Yarn Dyeing Ltd. & Mouchak \\
\hline 10 & N.T.K.C Apparels Ltd. & Bimail (Konabari) \\
\hline 11 & Pasha Yarn Dyeing & Sofipur (pollybiddyut) \\
\hline 12 & Islam Group & Zurun (Konabari) \\
\hline 13 & BSCIC-1 & Konabari \\
\hline 14 & Jalal Yarn Dyeing & Sofipur (pollybiddyut) \\
\hline 15 & Mondol Group of Company & Zurun (Konabari) \\
\hline 16 & R.L Yarn Dyeing & Sofipur (pollybiddyut) \\
\hline 17 & Purbani Fabrics Dyeing Limited & Mouchak \\
\hline 18 & A.T.S Apparels Limited & Mouchak \\
\hline 19 & IBN-SINA Pharmaceuticals & Sofipur (Gazipur) \\
\hline 20 & Standard Group & Zurun (Konabari) \\
\hline 21 & BSCIC-2 & Konabari \\
\hline 22 & New way Clothings & Mouchak \\
\hline 23 & Karooni Kniting Limited & Mouchak \\
\hline 24 & Shadin Group & Zurun (Konabari) \\
\hline 25 & Apex Dyeing Industries & Sofipur (pollybiddyut) \\
\hline 26 & Moazzem Kniting and Dyeing Industries & Zurun (Konabari) \\
\hline
\end{tabular}

The DO of all collected effluents samples were within the range of 0.3 to $1.5 \mathrm{mg} \mathrm{L}^{-1}$ with an average value of $0.59 \mathrm{mg} \mathrm{L}^{-1}(\mathrm{SD} \pm 0.25)$ (Table 2). Adequate dissolved oxygen is necessary for good water quality as well as to all forms of life. As dissolved oxygen levels in water drop below $5.0 \mathrm{mg} \mathrm{L}^{-1}$, aquatic life is put under stress. The acceptable range of DO for fish culture is $5 \mathrm{mg} \mathrm{L}^{-1}$ to saturation (Meade, 1998). On the basis of measured DO of all effluent samples collected from the Gazipur industrial area was problematic for aquatic life but DO is not essential for irrigation purposes. TDS values of collected effluent samples were within the range of 465 to $1587 \mathrm{mg} \mathrm{L}^{-1}$ with an average value of $957.57 \mathrm{mg} \mathrm{L}^{-1}(\mathrm{SD} \pm 293.07)$ (Table 2). Most of effluent samples containing TDS <
$1000 \mathrm{mg} \mathrm{L}^{-1}$ were rated as fresh water (Freeze and Cherry, 1979). High TDS values indicated the presence of an appreciable quantities of bicarbonates, sulphates and chlorides of $\mathrm{Ca}, \mathrm{Mg}$ and $\mathrm{Na}$ (Karanth, 1994). On the basis of measured TDS most of the collected effluent samples were rated as fresh water that is not problematic for irrigation purposes. A similar observation was reported by Singh et al. (2010) for waste water of Raniganj industrial area in India.

\section{b) Major anionic constituents in water}

Chloride concentration in collected effluent samples were ranging from 1.40 to $25.77 \mathrm{me} \mathrm{L}^{-1}$ with an average value of $5.92 \mathrm{me} \mathrm{L}^{-1}(\mathrm{SD} \pm 5.42)$ (Table 2) and 
contributed $44 \%$ of the total anionic balance (Fig. 1). Maximum permissible limit of $\mathrm{Cl}$ in irrigation water is $4.00 \mathrm{me} \mathrm{L}^{-1}\left(141.80 \mathrm{mg} \mathrm{L}^{-1}\right)$ as reported by Ayers and Westcot (1985). On the basis of this report, only 9 effluent samples were within the permissible limit and suitable for irrigation and the rest 18 effluent samples were exceed the permissible limit and not suitable for irrigation. Excess chloride in the study area may result from anthropogenic sources including domestic and industrial wastes water (Appelo and Postma, 1993). The concentration of $\mathrm{HCO}_{3}$ in effluent samples were within the range of 4.0 to $14.0 \mathrm{me} \mathrm{L}^{-1}$ with the mean value of $7.31 \mathrm{me} \mathrm{L}^{-1}(\mathrm{SD} \pm 2.51)$ (Table 2) and contributed $55 \%$ of the total anionic balance (Fig. 1). In respect of $\mathrm{HCO}_{3}$ content, all of the studied effluent samples were found unsuitable for irrigation, which exceed the recommended limit $\left(1.50 \mathrm{me} \mathrm{L}^{-1}\right)$ as reported by Ayers and Westcot (1985).

Table 2: Physicochemical properties and major anionic constituents of effluent collected from the major polluting industrial areas of Gazipur in Bangladesh

\begin{tabular}{|c|c|c|c|c|c|c|c|c|c|}
\hline $\begin{array}{c}\text { Sample } \\
\text { ID }\end{array}$ & pH & $\begin{array}{c}\mathrm{EC} \\
\mu \mathrm{S} \mathrm{cm}^{-1}\end{array}$ & $\begin{array}{c}\text { DO } \\
\text { mg L L }^{-1}\end{array}$ & $\begin{array}{c}\text { TDS } \\
\text { mg L }^{-1}\end{array}$ & $\begin{array}{c}\mathrm{Cl} \\
\mathrm{me} \mathrm{L}^{-1}\end{array}$ & $\begin{array}{c}\mathrm{CO}_{3} \\
\mathrm{me} \mathrm{L}^{-1}\end{array}$ & 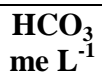 & $\begin{array}{c}\mathrm{PO}_{4} \\
\mathrm{mg} \mathrm{L}^{-1}\end{array}$ & $\begin{array}{c}\mathrm{SO}_{4} \\
\mathrm{mg} \mathrm{L}^{-1}\end{array}$ \\
\hline 1 & 6.89 & 1995 & 0.80 & 1366 & 25.77 & Trace & 9.00 & 0.061 & 0.136 \\
\hline 2 & 6.65 & 1560 & 0.40 & 1052 & 1.93 & Trace & 6.00 & 0.053 & 0.072 \\
\hline 3 & 6.90 & 1880 & 0.40 & 1150 & 5.49 & Trace & 10.00 & 0.139 & 0.205 \\
\hline 4 & 6.89 & 1890 & 0.40 & 1130 & 9.00 & Trace & 14.00 & 0.102 & 0.057 \\
\hline 5 & 6.18 & 1370 & 0.60 & 950 & 4.78 & Trace & 9.00 & 0.077 & 0.274 \\
\hline 6 & 7.28 & 1890 & 0.40 & 1233 & 16.89 & Trace & 8.00 & 0.075 & 0.954 \\
\hline 7 & 7.01 & 1130 & 0.70 & 720 & 2.81 & Trace & 6.00 & 0.135 & 0.249 \\
\hline 8 & 6.67 & 195 & 0.30 & 1587 & 14.36 & Trace & 6.00 & 0.081 & 0.282 \\
\hline 9 & 6.05 & 1720 & 0.90 & 1071 & 1.40 & Trace & 8.00 & 0.044 & 0.465 \\
\hline 10 & 7.09 & 1380 & 0.50 & 921 & 4.78 & Trace & 8.00 & 0.084 & 0.143 \\
\hline 11 & 6.52 & 1780 & 0.70 & 1088 & 6.47 & Trace & 9.00 & 0.285 & 0.283 \\
\hline 12 & 6.69 & 181 & 0.30 & 1450 & 2.53 & Trace & 11.00 & 0.032 & 0.541 \\
\hline 13 & 6.28 & 1380 & 0.60 & 720 & 5.34 & Trace & 4.00 & 0.015 & 0.204 \\
\hline 14 & 6.75 & 1900 & 0.70 & 1322 & 7.60 & Trace & 9.00 & 0.051 & 0.030 \\
\hline 15 & 6.19 & 1160 & 0.50 & 739 & 2.81 & Trace & 5.00 & 0.041 & 0.193 \\
\hline 16 & 6.35 & 1760 & 0.60 & 1125 & 4.78 & Trace & 8.00 & 0.053 & 0.235 \\
\hline 17 & 6.15 & 780 & 1.50 & 486 & 4.93 & Trace & 10.00 & 0.258 & 0.370 \\
\hline 18 & 6.39 & 1010 & 0.60 & 641 & 4.22 & Trace & 7.00 & 0.146 & 0.057 \\
\hline 19 & 7.08 & 990 & 0.90 & 629 & 2.53 & Trace & 6.00 & 0.175 & 0.045 \\
\hline 20 & 6.57 & 1520 & 0.30 & 955 & 1.55 & Trace & 4.00 & 0.077 & 0.407 \\
\hline 21 & 6.26 & 1360 & 0.50 & 887 & 5.49 & Trace & 5.00 & 0.047 & 0.102 \\
\hline 22 & 7.15 & 1010 & 0.80 & 627 & 4.08 & Trace & 9.00 & 0.047 & 0.069 \\
\hline 23 & 6.61 & 1660 & 0.50 & 930 & 2.53 & Trace & 4.00 & 0.123 & 0.662 \\
\hline 24 & 6.91 & 1140 & 0.60 & 740 & 4.50 & Trace & 4.00 & 0.010 & 0.180 \\
\hline 25 & 6.43 & 750 & 0.50 & 465 & 2.11 & Trace & 5.00 & 0.038 & 0.067 \\
\hline 26 & 6.75 & 1380 & 0.40 & 913 & 5.34 & Trace & 6.00 & 0.103 & 0.121 \\
\hline Max. & 7.28 & 1995 & 1.50 & 1587 & 25.77 & Trace & 14.00 & 0.29 & 0.95 \\
\hline Min. & 6.05 & 181 & 0.30 & 465 & 1.40 & Trace & 4.00 & 0.01 & 0.03 \\
\hline Mean & 6.64 & 1337.35 & 0.59 & 957.57 & 5.92 & Trace & 7.31 & 0.09 & 0.25 \\
\hline SD & 0.35 & 494.50 & 0.25 & 293.07 & 5.42 & Trace & 2.51 & 0.07 & 0.22 \\
\hline
\end{tabular}

The phosphate content of collected effluent samples were varied from 0.01 to $0.29 \mathrm{mg} \mathrm{L}^{-1}$ with a mean value of $0.09 \mathrm{mg} \mathrm{L}^{-1}(\mathrm{SD} \pm 0.07)$ (Table 2). Maximum permissible limit of $\mathrm{PO}_{4}$ in irrigation water is $2.00 \mathrm{mg}$ $\mathrm{L}^{-1}$ (Ayers and Westcot, 1985). Considering this value as standard out of the 26 effluent samples, all the samples were within the permissible limit and suitable for irrigation. The $\mathrm{SO}_{4}$ content of all collected effluent samples were ranged between 0.03 to $0.95 \mathrm{mg} \mathrm{L}^{-1}$ with a mean value of $0.25 \mathrm{mg} \mathrm{L}^{-1}$ $(\mathrm{SD} \pm 0.22)$ (Table 2$)$ and contributed $1 \%$ of the total anionic balance (Fig. 1). Maximum permissible limit of $\mathrm{SO}_{4}$ in irrigation water is $20.00 \mathrm{mg} \mathrm{L}^{-1}$ (Ayers and Westcot, 1985). Out of the 26 effluent samples, all the samples were within the permissible value and suitable for irrigation. 

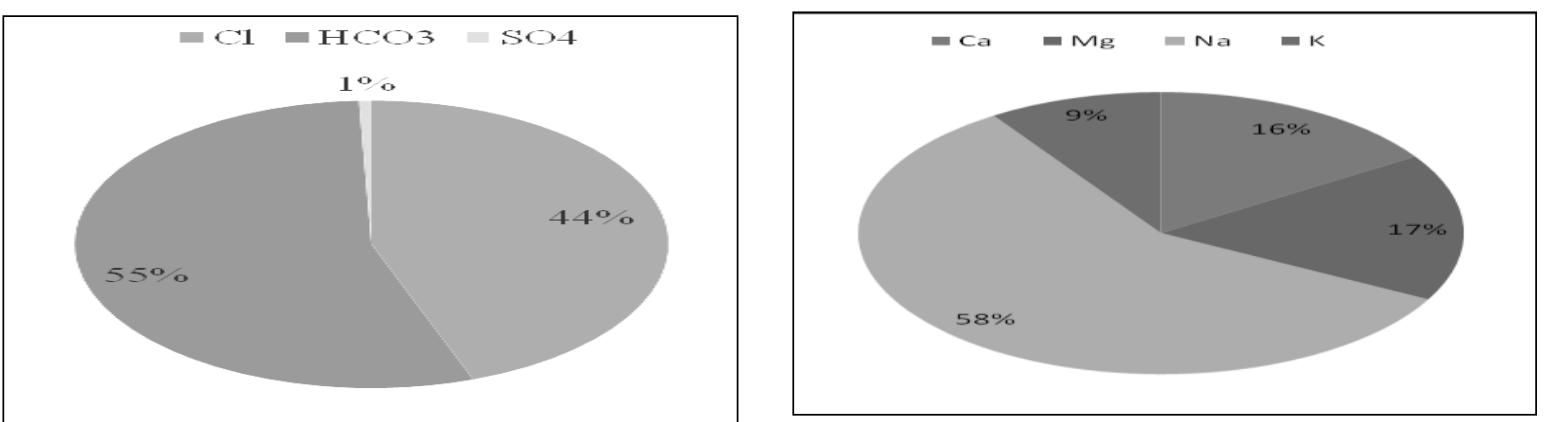

Fig. 1: Contribution of individual major ions towards the total anionic (a) and cationic (b) mass balance in effluent of major polluting areas of Gazipur, Bangladesh

\section{c) Major cationic constituents in water}

The content of $\mathrm{Ca}$ in collected effluent samples were varied between Trace to $80.16 \mathrm{mg} \mathrm{L}^{-1}$ with an average value of $43.16 \mathrm{mg} \mathrm{L}^{-1}(\mathrm{SD} \pm 14.01)$ (Table 3) and contributed $16 \%$ of the total cationic mass balance (Fig. 1). The contribution of $\mathrm{Ca}$ in effluent was largely dependent on the solubility of $\mathrm{CaCO}_{3}, \mathrm{CaSO}_{4}$ and rarely on $\mathrm{CaCl}_{2}$ (Karanth, 1994). Irrigation water containing less than $20 \mathrm{me} \mathrm{L}^{-1}\left(800 \mathrm{mg} \mathrm{L}^{-1}\right) \mathrm{Ca}$ that is suitable for irrigating crops (Ayers and Westcot, 1985). On the basis of Ca content, all effluent samples could safely be used for irrigation and soils of the study area would not be affected.

The concentration of $\mathrm{Mg}$ in collected effluent samples were detected within the range of 21.87 to $92.32 \mathrm{mg}$ $\mathrm{L}^{-1}$ with an average value of $46.06 \mathrm{mg} \mathrm{L}^{-1}(\mathrm{SD} \pm 13.96)$ (Table 3) which contributed $17 \%$ of the total cationic balance (Fig. 1). According to Ayers and Westcot (1985), irrigation water containing below $5.0 \mathrm{me} \mathrm{L}^{-1}$ $\left(121.5 \mathrm{mg} \mathrm{L}^{-1}\right) \mathrm{Mg}$ that is suitable for crops and soils. Considering this as standard, all effluent samples were within this recommended limit and could safely be used for irrigation and would not affect soils of the study area. The content of $\mathrm{Na}$ in collected effluent samples were varied from 36.58 to $379.29 \mathrm{mg} \mathrm{L}^{-1}$ with the mean value of $157.54 \mathrm{mg} \mathrm{L}^{-1}(\mathrm{SD} \pm 118.7)$ (Table 3) and contributed $58 \%$ of the total cationic mass balance (Fig. 1). Na in the aquatic system is mainly derived from atmospheric deposition; evaporate dissolution and silicate weathering (Berner and Berner, 1987). According to Ayers and Westcot (1985), irrigation water generally containing less than $40 \mathrm{me} \mathrm{L}^{-1} \mathrm{Na}$ that is suitable for crops and soils. The detected $\mathrm{Na}$ content in all the effluent samples under test were far below this specified limit and could safely be applied for long-term irrigation without any harmful effect on soils and crops. The concentration of $\mathrm{K}$ present in collected effluent samples were varied from 11.71 to $64.75 \mathrm{mg} \mathrm{L}^{-1}$ with the mean value of
$25.43 \mathrm{mg} \mathrm{L}^{-1}(\mathrm{SD} \pm 11.62)$ (Table 3) and contributed 9 $\%$ of the total cationic mass balance (Fig. 1). According to Ayers and Westcot (1985), the recommended limit of $\mathrm{K}$ in irrigation water is $2.0 \mathrm{mg}$ $\mathrm{L}^{-1}$. In the investigated area, all of the effluent samples exceeded the permissible limit for irrigation purposes.

\section{d)Heavy metal concentration in water}

Table 3 showed the concentration of trace metals found in collected effluent samples. The Fe content of collected effluent samples ranging from trace to 0.27 $\mathrm{mg} \mathrm{L} \mathrm{L}^{-1}$ with an average value of $0.02 \mathrm{mg} \mathrm{L}^{-1}$ $(\mathrm{SD} \pm 0.09) \quad$ (Table 3). According to Ayers and Westcot (1985), maximum recommended concentration of $\mathrm{Fe}$ in water used for irrigation is 5.0 $\mathrm{mg} \mathrm{L}^{-1}$. Considering this limit as standard, amount of $\mathrm{Fe}$ in all effluent samples of the study area were below the recommended value and suitable for irrigation. The concentration of $\mathrm{Mn}$ in collected effluent samples were ranging from Trace to $0.29 \mathrm{mg}$ $\mathrm{L}^{-1}$ with an average value of $0.04 \mathrm{mg} \mathrm{L}^{-1}(\mathrm{SD} \pm 0.08)$ (Table 3). According to Ayers and Westcot (1985), maximum recommended limit of $\mathrm{Mn}$ in water used for irrigation is $0.20 \mathrm{mg} \mathrm{L}^{-1}$. Considering this limit as standard, amount of $\mathrm{Mn}$ in all effluent samples except one (Sample No. 6) of the study area were below the recommended value that is suitable for irrigation. The collected effluent samples contained $\mathrm{Cu}$ were varied from Trace to $4.91 \mathrm{mg} \mathrm{L}^{-1}$ with an average value of $0.19 \mathrm{mg} \mathrm{L}^{-1}$ (Table 3). Among the 26 effluent samples except one sample (Samples no. 17), all samples were found within the recommended limit as described by Ayers and Westcot (1985) for irrigation where its acceptable limit is $0.20 \mathrm{mg} \mathrm{L}^{-1}$. The National Academy of Science has recommended that for continuous use irrigation effluent water should contain no more than $0.2 \mathrm{mg} \mathrm{L}^{-1} \mathrm{Cu}$ (Gibeault and Cockerham, 1985). Zn concentration in collected effluent samples from the Gazipur industrial areas varied from Trace to $0.01 \mathrm{mg} \mathrm{L}^{-1}$ with an average 161 value of $0.001 \mathrm{mg} \mathrm{L}^{-1}(\mathrm{SD} \pm 0.005)$ (Table 3). The 
National Academy of Science has recommended that for continuous use of irrigation for effluent should contain $\mathrm{Zn}$ no more than $5.0 \mathrm{mg} \mathrm{L}^{-1}$ (Gibeault and Cockerham, 1985). On the other hand, according to Ayers and Westcot (1985) the maximum permissible limit of $\mathrm{Zn}$ in irrigation water is $2.00 \mathrm{mg} \mathrm{L}^{-1}$. Considering this limit as standard, all effluent samples were found within the maximum permissible limits which were suitable for irrigation in respect of $\mathrm{Zn}$. The collected effluent samples contained $\mathrm{Pb}$ were fluctuated from Trace to $0.24 \mathrm{mg} \mathrm{L}^{-1}$ with an average value of $0.05 \mathrm{mg} \mathrm{L}^{-1}(\mathrm{SD} \pm 0.06$ ) (Table 3). According to Ayers and Westcot (1985), the standard limit of lead is $5.00 \mathrm{mg} \mathrm{L}^{-1}$ for irrigation purposes, which indicates that all of these effluent can safely be used for

Table 3: Heavy metals and major cationic constituents of effluent collected from Gazipur industrial area in Bangladesh

\begin{tabular}{|c|c|c|c|c|c|c|c|c|c|c|}
\hline $\begin{array}{l}\text { Sample } \\
\text { ID }\end{array}$ & $\begin{array}{c}\mathrm{Ca} \\
\mathrm{mg} \mathrm{L}^{-1}\end{array}$ & $\begin{array}{c}\mathrm{Mg} \\
\mathrm{mg} \mathrm{L}^{-1}\end{array}$ & $\begin{array}{c}\mathrm{Na} \\
\mathrm{mg} \mathrm{L}^{-1}\end{array}$ & $\begin{array}{c}\mathbf{K} \\
\mathrm{mg} \mathrm{L}^{-1}\end{array}$ & $\begin{array}{c}\mathrm{Mn} \\
\mathrm{mg} \mathrm{L}^{-1}\end{array}$ & $\begin{array}{c}\mathrm{Cu} \\
\mathrm{mg} \mathrm{L}^{-1}\end{array}$ & $\begin{array}{c}\mathrm{Zn} \\
\mathrm{mg} \mathrm{L}^{-1}\end{array}$ & $\begin{array}{c}\mathbf{P b} \\
\mathrm{mg} \mathrm{L}^{-1}\end{array}$ & $\begin{array}{c}\mathrm{Fe} \\
\mathrm{mg} \mathrm{L}^{-1}\end{array}$ & $\begin{array}{c}\mathrm{Cd} \\
\mathrm{mg} \mathrm{L}^{-1}\end{array}$ \\
\hline 1 & 60.12 & 38.88 & 290.65 & 11.71 & Trace & Trace & Trace & Trace & Trace & Trace \\
\hline 2 & 36.07 & 46.17 & 251.97 & 12.92 & 0.156 & Trace & Trace & Trace & 0.113 & Trace \\
\hline 3 & 56.11 & 55.89 & 62.71 & 48.95 & Trace & Trace & Trace & Trace & Trace & Trace \\
\hline 4 & Trace & 60.75 & 67.23 & 17.38 & 0.179 & Trace & Trace & Trace & Trace & Trace \\
\hline 5 & 48.09 & 43.74 & 36.58 & 27.10 & Trace & Trace & 0.004 & 0.082 & Trace & Trace \\
\hline 6 & 40.08 & 51.03 & 67.46 & 64.75 & 0.286 & Trace & Trace & 0.106 & Trace & Trace \\
\hline 7 & 52.14 & 48.60 & 85.33 & 23.04 & Trace & Trace & Trace & 0.094 & Trace & Trace \\
\hline 8 & 32.06 & 31.59 & 355.17 & 24.25 & Trace & Trace & Trace & 0.175 & Trace & Trace \\
\hline 9 & 60.12 & 43.74 & 273.77 & 44.04 & Trace & Trace & Trace & 0.235 & Trace & Trace \\
\hline 10 & Trace & 43.74 & 92.36 & 26.28 & Trace & Trace & Trace & 0.036 & Trace & Trace \\
\hline 11 & Trace & 48.60 & 322.01 & 23.04 & 0.102 & Trace & Trace & 0.036 & 0.075 & Trace \\
\hline 12 & Trace & 21.87 & 249.14 & 23.44 & Trace & Trace & Trace & 0.129 & Trace & Trace \\
\hline 13 & 60.12 & 36.45 & 92.86 & 23.45 & 0.009 & Trace & Trace & 0.153 & Trace & Trace \\
\hline 14 & 44.08 & 48.60 & 352.16 & 25.47 & Trace & Trace & Trace & Trace & Trace & Trace \\
\hline 15 & 32.06 & 31.59 & 89.35 & 20.62 & 0.019 & Trace & Trace & Trace & Trace & Trace \\
\hline 16 & 44.08 & 40.74 & 337.08 & 23.04 & 0.020 & Trace & Trace & Trace & Trace & Trace \\
\hline 17 & 60.12 & 29.16 & 73.77 & 16.97 & Trace & 4.91 & 0.011 & Trace & 0.272 & Trace \\
\hline 18 & 72.14 & 60.75 & 62.71 & 22.23 & Trace & Trace & Trace & Trace & Trace & Trace \\
\hline 19 & 64.13 & 58.32 & 58.19 & 31.55 & 0.083 & Trace & Trace & Trace & Trace & Trace \\
\hline 20 & 44.08 & 36.45 & 98.89 & 12.92 & Trace & Trace & Trace & Trace & Trace & Trace \\
\hline 21 & 40.08 & 41.41 & 93.87 & 23.04 & Trace & Trace & Trace & Trace & Trace & Trace \\
\hline 22 & 44.13 & 55.89 & 63.22 & 21.83 & 0.090 & Trace & 0.001 & Trace & Trace & Trace \\
\hline 23 & 80.16 & 63.18 & 379.29 & 31.54 & 0.107 & Trace & 0.011 & 0.059 & 0.143 & Trace \\
\hline 24 & 64.12 & 53.46 & 80.80 & 21.02 & 0.040 & Trace & Trace & 0.008 & Trace & Trace \\
\hline 25 & 48.09 & 51.03 & 66.73 & 14.54 & 0.006 & Trace & Trace & 0.094 & Trace & Trace \\
\hline 26 & 40.08 & 92.32 & 92.86 & 26.28 & 0.022 & Trace & Trace & 0.153 & 0.019 & Trace \\
\hline Max. & 80.16 & 92.32 & 379.29 & 64.75 & 0.29 & 4.91 & 0.01 & 0.24 & 0.27 & Trace \\
\hline Min. & Trace & 21.87 & 36.58 & 11.71 & Trace & Trace & Trace & Trace & Trace & Trace \\
\hline Mean & 43.16 & 46.06 & 157.54 & 25.43 & 0.04 & 0.19 & 0.001 & 0.05 & 0.02 & Trace \\
\hline SD & 14.01 & 13.96 & 118.70 & 11.62 & 0.08 & - & 0.005 & 0.06 & 0.09 & - \\
\hline
\end{tabular}

\section{(i) Sodium adsorption ratio (SAR)}

A high $\mathrm{Na}$ concentration changes soil properties and reduces soil permeability, which leads to development of an alkaline soil (Singh et al., 2010). The $\mathrm{Na}$ or alkali hazard is determined by the absolute and relative concentration of cations and is expressed in irrigation as well as other purposes in respect of lead. The concentration of $\mathrm{Cd}$ in collected effluent samples were Trace in amount of $\mathrm{Cd}$. Considering these amount of $\mathrm{Cd}$ in industrial effluent, all the effluents samples were suitable for irrigation in respect of cadmium.

\section{e) Suitability of water for irrigation usage}

The important characteristics or properties of water to be considered for irrigation use are electrical conductivity, salinity, percent sodium, sodium adsorption ratio, residual sodium carbonate and permeability index. 
The computed SAR of effluent samples were ranged from 2.66 to 45.9 with a mean value of 12.6 (SD \pm 11.13 ) (Table 4). According to Todd (1980) categorized irrigation water into 4 groups. Considering this classification, 17 effluent samples were graded as excellent category for irrigation purpose, 6 were graded as fair and the rest 3 effluent samples were graded as poor for irrigation purposes. The present investigation revealed that a good proportion of $\mathrm{Ca}$ and $\mathrm{Mg}$ existed in all effluent. These were suitable for good structure and tilth condition of soil and also the improvement of soil permeability. The plot of data on the US salinity diagram as described by Richards (1968), in which the EC is taken as salinity hazard and SAR as alkalinity hazard shows that effluents samples were in the category of C3S4, C3S1, C1S4, C3S2 and C2S1 indicating low alkalinity to high salinity and low alkali hazard (Fig. 2). Low sodium water (S1) can be used for irrigation on almost all soils with little danger of the development of harmful levels of exchangeable sodium.

Table 4: Quality rating and suitability of water for irrigation collected from the major polluting areas of Gazipur industrial area in Bangladesh

\begin{tabular}{|c|c|c|c|c|c|c|c|c|c|}
\hline \multirow{2}{*}{$\begin{array}{c}\text { Sample } \\
\text { ID }\end{array}$} & \multirow{2}{*}{ SAR } & \multirow{2}{*}{ SSP\% } & \multirow{2}{*}{$\begin{array}{c}\mathrm{RSC}^{-1} \\
\mathrm{meL}^{-1}\end{array}$} & \multirow{2}{*}{$\begin{array}{c}\text { Hard- } \\
\text { ness } \\
\text { mgL }^{-1}\end{array}$} & \multicolumn{4}{|c|}{ Water class based on } & \multirow{2}{*}{$\begin{array}{c}\text { Alkalinity } \& \\
\text { salinity } \\
\text { hazard } \\
\text { classes }\end{array}$} \\
\hline & & & & & $\mathbf{S A R}^{1}$ & $\mathbf{S S P}^{2}$ & $\mathbf{R S C}^{3}$ & Hardness $^{4}$ & \\
\hline 1 & 20.4 & 89.25 & -0.59 & 309.7 & Fair & Doubt. & Suit. & $\mathrm{VH}$ & C3S4 \\
\hline 2 & 18.7 & 88.95 & 2.70 & 279.4 & Fair & Doubt. & Unsuit. & Hard & C3S4 \\
\hline 3 & 4.06 & 64.68 & 0.20 & 379.5 & Ex. & Doubt. & Suit. & $\mathrm{VH}$ & C3S1 \\
\hline 4 & 5.21 & 71.51 & 11.50 & 249.0 & Ex. & Doubt. & Unsuit. & Hard & C3S1 \\
\hline 5 & 2.66 & 56.87 & 4.50 & 489.4 & Ex. & Perm. & Unsuit. & VH & C3S1 \\
\hline 6 & 4.75 & 70.95 & 3.20 & 309.7 & Ex. & Doubt. & Unsuit. & $\mathrm{VH}$ & C3S1 \\
\hline 7 & 5.82 & 70.98 & 3.90 & 329.5 & Ex. & Doubt. & Unsuit. & $\mathrm{VH}$ & C3S1 \\
\hline 8 & 30.5 & 93.83 & 1.40 & 209.6 & Poor & Doubt. & Mar. & Hard & C1S4 \\
\hline 9 & 18.8 & 88.51 & 4.70 & 329.6 & Fair & Doubt. & Unsuit. & $\mathrm{VH}$ & C3S4 \\
\hline 10 & 5.57 & 82.96 & 1.00 & 299.7 & Ex. & Doubt. & Suit. & Hard & C3S1 \\
\hline 11 & 28.4 & 93.55 & 9.00 & 199.2 & Poor & Doubt. & Unsuit. & Hard & C3S4 \\
\hline 12 & 45.9 & 97.21 & 6.10 & 89.66 & Poor & Doubt. & Unsuit. & $\mathrm{MH}$ & C1S4 \\
\hline 13 & 8.52 & 74.43 & 1.70 & 329.4 & Ex. & Doubt. & Mar. & $\mathrm{VH}$ & C3S2 \\
\hline 14 & 24.9 & 91.09 & 16.0 & 348.8 & Fair & Doubt. & Unsuit. & $\mathrm{VH}$ & C3S4 \\
\hline 15 & 7.64 & 79.92 & 4.90 & 209.6 & Ex. & Doubt. & Unsuit. & Hard & C3S2 \\
\hline 16 & 24.7 & 91.27 & 11.1 & 389.4 & Fair & Doubt. & Unsuit. & Hard & C3S4 \\
\hline 17 & 5.57 & 71.77 & 7.20 & 179.3 & Ex. & Doubt. & Unsuit. & Hard & C3S1 \\
\hline 18 & 4.57 & 58.63 & 2.00 & 399.4 & Ex. & Perm. & Mar. & $\mathrm{VH}$ & C3S1 \\
\hline 19 & 3.76 & 59.76 & 5.90 & 749.9 & Ex. & Perm. & Unsuit. & $\mathrm{VH}$ & C3S1 \\
\hline 20 & 7.59 & 77.56 & 6.30 & 369.4 & Ex. & Doubt. & Unsuit. & $\mathrm{VH}$ & C3S2 \\
\hline 21 & 7.08 & 76.54 & 2.30 & 269.7 & Ex. & Doubt. & Mar. & Hard & C3S2 \\
\hline 22 & 3.98 & 61.10 & 9.30 & 269.8 & Ex. & Doubt. & Unsuit. & Hard & C3S1 \\
\hline 23 & 22.2 & 88.15 & 2.90 & 459.4 & Fair & Doubt. & Unsuit. & $\mathrm{VH}$ & C3S4 \\
\hline 24 & 5.14 & 66.75 & 5.10 & 289.5 & Ex. & Doubt. & Unsuit. & Hard & C3S2 \\
\hline 25 & 6.64 & 65.42 & 2.70 & 429.4 & Ex. & Doubt. & Unsuit. & $\mathrm{VH}$ & $\mathrm{C} 2 \mathrm{~S} 1$ \\
\hline 26 & 5.25 & 64.72 & 1.20 & 478.7 & Ex. & Doubt. & Suit. & $\mathrm{VH}$ & C3S1 \\
\hline Max. & 45.9 & 97.55 & 16.00 & 749.9 & & & & & \\
\hline Min. & 2.66 & 56.87 & -0.59 & 89.66 & & & & & \\
\hline Mean & 12.6 & 67.75 & 4.84 & 331.7 & & & & & \\
\hline SD & 11.13 & 4.19 & 3.93 & 127.9 & & & & & \\
\hline
\end{tabular}

Legend: Ex. = Excellent, Perm. $=$ Permissible, Doubt $=$ Doubtful, MH $=$ Moderately hard, VH $=$ Very hard, Suit. $=$ Suitable, Unsuit.= Unsuitable, Mar. = Marginal, C2 = Medium Salinity, C3 = High Salinity and S1 = Low alkalinity. ${ }^{1,2,3 \& 4}=$ According to Appendix 1, 2, 3 \& 4, respectively. ${ }^{5}=$ According to Fig. 2. 


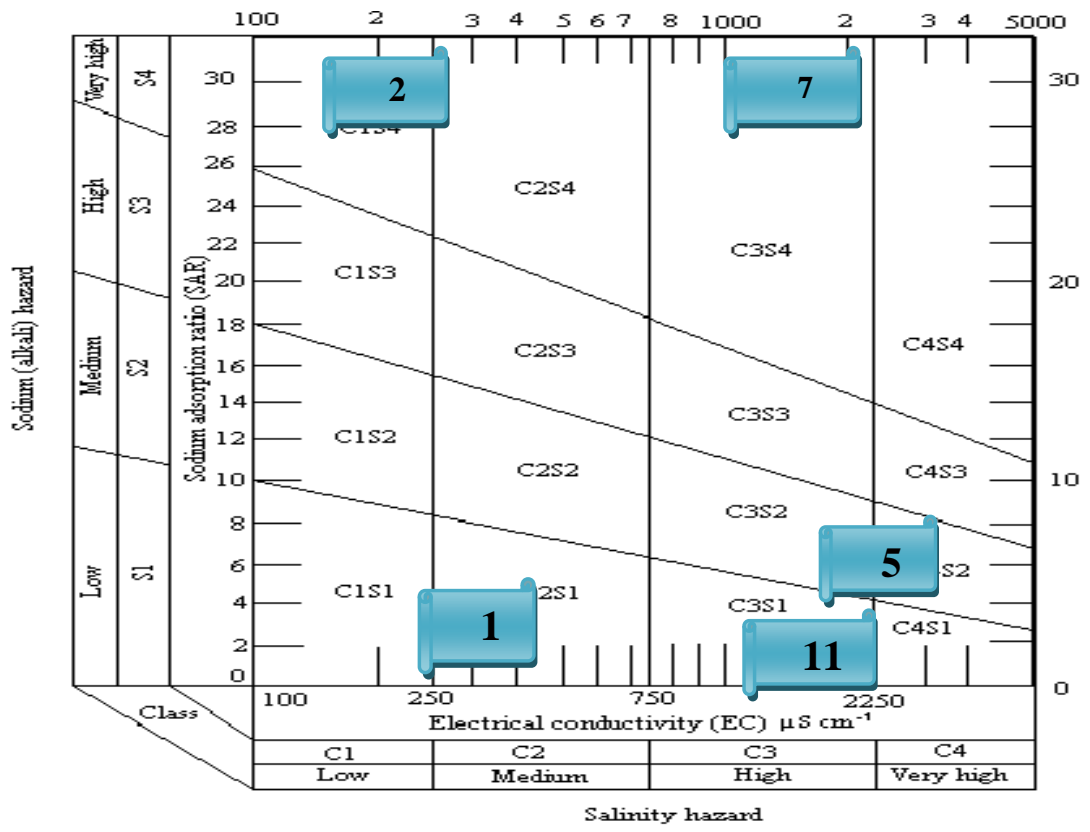

Fig. 2: Diagram for classifying irrigation water on the basis of SAR and EC as described by Richards (1968)

\section{(ii) Soluble sodium percentage (SSP)}

Percent $\mathrm{Na}$ is widely used for evaluating the suitability of water for irrigation (Wilcox, 1955). High $\mathrm{Na}$ irrigation water causes exchange of $\mathrm{Na}$ in water for $\mathrm{Ca}$ and $\mathrm{Mg}$ in soil, reduces permeability, and eventually results in soil with poor internal drainage. Hence, air and water circulation is restricted during wet conditions and such soils are usually hard when dry (Collins and Jenkins, 1996; Saleh et al., 1999). The Indian Standard (BIS, 1991) recommends a maximum SSP of $60 \%$ for irrigation water, where SSP is calculated by:

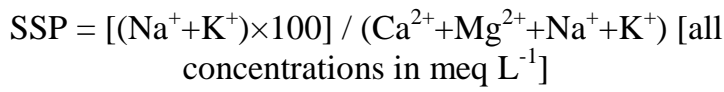

The calculated soluble sodium percentage (SSP) values of all collected effluent samples were varied from 56.87 to $97.55 \%$ with the mean value of $67.75 \%$ (SD \pm 4.19$) \quad$ (Table 4). According to water classification proposed by Wilcox (1955), out of 26 effluent samples, 3 samples were classified as permissible limit (SSP $=40-60 \%), 23$ samples were classified as doubtful. In the study area, the effluent having permissible limit classes might safely be applied for irrigating agricultural crops but the effluent samples exceed the permissible limit considered as toxic for irrigation.

\section{(iii) Residual sodium carbonate (RSC)}

The quantity of bicarbonate and carbonate in excess of alkaline earths $\left(\mathrm{Ca}^{2+}+\mathrm{Mg}^{2+}\right)$ also influence the suitability of water for irrigation purposes. When the sum of carbonates and bicarbonates is in excess of calcium and magnesium, precipitation $\mathrm{Ca}$ and $\mathrm{Mg}$ may occur (Raghunath, 1987). The effects of carbonate and bicarbonate, and suitability of water for irrigation can be assessed by computing residual sodium carbonate (RSC) values as follows:

$$
\begin{gathered}
\mathrm{RSC}=\left(\mathrm{CO}_{3}{ }^{2-}+\mathrm{HCO}_{3}{ }^{-}\right)-\left(\mathrm{Ca}^{2+}+\mathrm{Mg}^{2+}\right) \\
\text { [all concentrations in meq } \left.\mathrm{L}^{-1}\right]
\end{gathered}
$$

A high RSC value in water leads to an increase in the adsorption of $\mathrm{Na}$ on soil. Irrigation water having RSC values greater than $5 \mathrm{me} \mathrm{L}^{-1}$ are considered harmful to the growth of plants, while water with RSC value above $2.5 \mathrm{me}^{-1}$ are not considered suitable for irrigation. Hence, continued usage of high RSC water will affect the yields of crop. The computed RSC varied from -0.59 to $16 \mathrm{me} \mathrm{L}^{-1}$ with mean value of $4.84 \mathrm{me} \mathrm{L}^{-1}(\mathrm{SD} \pm 3.93)$ (Table 4). Among the effluent samples under test, 1 sample exhibited negative value. According to Ghosh et al. (1983), out of 26 effluent samples, 4 samples were found in suitable class (RSC $\left.<1.25 \mathrm{me} \mathrm{L}^{-1}\right), 4$ samples were in marginal class $\left(\mathrm{RSC}=1.25-2.50 \mathrm{me} \mathrm{L}^{-1}\right)$ and the rest 18 sample were found in unsuitable class $\left(\mathrm{RSC}>2.50 \mathrm{me} \mathrm{L}^{-1}\right)$.

\section{(iv)Hardness $\left(\mathbf{H}_{\mathrm{T}}\right)$}

Water hardness has no known adverse effects on human; however, some evidence indicates its role in heart disease (WHO, 2008). Hardness of water resulted due to the abundant presence of divalent cations like $\mathrm{Ca}^{2+}$ and $\mathrm{Mg}^{2+}$ (Todd, 1980). Hard water is unsuitable for domestic usage, as well as hardness of water limits its use for industrial purposes; causing 
scaling of pots, boilers and irrigation pipes may cause health problems to humans, such as kidney failure (WHO, 2008). Hardness of water was computed by the following formula:

$$
\mathrm{H}_{\mathrm{T}}=2.5 \times \mathrm{Ca}^{2+}+4.1 \times \mathrm{Mg}^{2+}
$$

The calculated hardness of all effluent samples varied from 89.66 to $749.9 \mathrm{mg} \mathrm{L}^{-1}$ with a mean value of $331.7 \mathrm{mg} \mathrm{L}^{-1}(\mathrm{SD} \pm 127.9)$ (Table 4). On the basis of total hardness, water was classified as soft $(<75 \mathrm{mg}$ $\left.\mathrm{L}^{-1}\right)$, moderately hard (75-150 $\left.\mathrm{mg} \mathrm{L}^{-1}\right)$, hard (150-300 $\mathrm{mg} \mathrm{L}^{-1}$ ) and very hard (> $300 \mathrm{mg} \mathrm{L}^{-1}$ ) (Sawyer and McCarty, 1967). According to the criteria described above, among the 26 effluent samples collected from the Gazipur industrial area, 1 sample were graded as moderately hard, 11 samples were graded as hard and the rest 14 effluent samples were graded as very hard.

\section{(v) Permeability index (PI)}

Soil permeability is affected by long term use of water rich in $\mathrm{Na}^{+}, \mathrm{Ca}^{2+}, \mathrm{Mg}^{2+}$ and $\mathrm{HCO}_{3}$. The $\mathrm{PI}$ is also used to assess suitability of water for irrigation and is defined as follows:

$\mathrm{PI}=\left[\left(\mathrm{Na}^{+}+\sqrt{ } \mathrm{HCO}_{3}{ }^{-}\right) \times 100\right] /\left(\mathrm{Ca}^{2+}+\mathrm{Mg}^{2+}+\mathrm{Na}^{+}\right)$ [all concentrations in meq $\mathrm{L}^{-1}$ ]

Doneen (1964) classified irrigation water in three permeability index classes. Class-I and Class-II water types are suitable for irrigation with $75 \%$ or more of maximum permeability, while Class-III types of water with $25 \%$ of maximum permeability are unsuitable for irrigation. Plotting data on Doneen's chart indicates that no water samples fall in Class-I and 19 in Class-II, implying that the water is good for irrigation uses (Domenico and Schwartz, 1990).

However, 7 water samples belong to Class-III, the unsuitable category (Fig. 3).

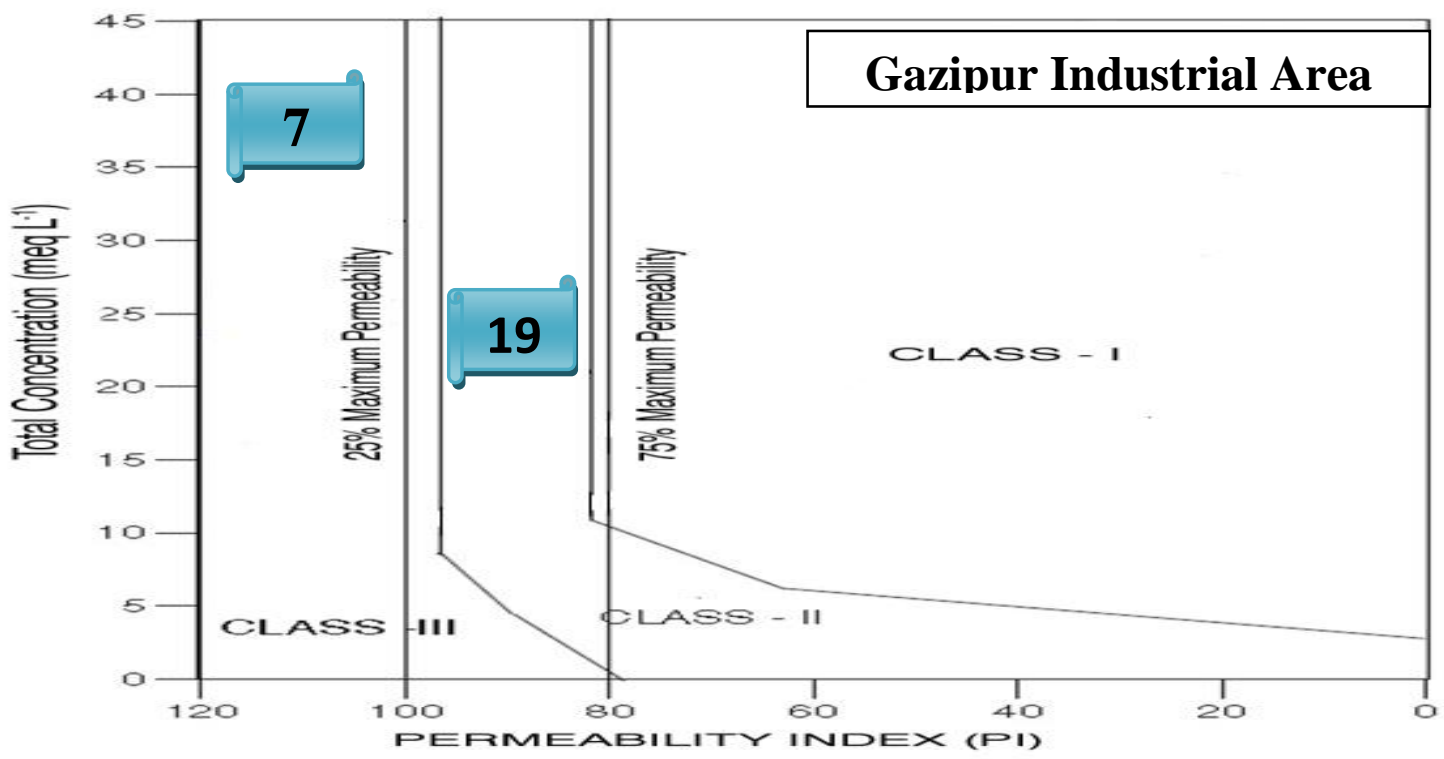

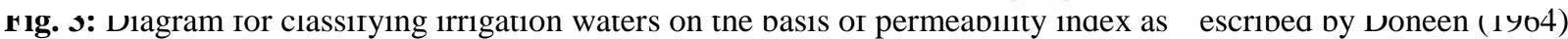

\section{f) Relationship between water quality factors and ionic constituents}

Correlation matrix for analyzed parameters of effluents were calculated to see if some of the parameters were interrelated with each other and the results are presented in Tables 5 ( $\mathrm{a} \& \mathrm{~b}$ ). Examination of the matrix also provides clues about the carrier substances and the chemical association of ionic constituents in the study area (Jaquet et al., 1982). Considering the relationship between ionic constituents of water, the combinations of TDS vs
SSP, TDS vs SAR, SAR vs SSP, Ca vs Zn; Ca vs Fe ; $\mathrm{Mg}$ vs $\mathrm{Fe}$; $\mathrm{Na}$ vs $\mathrm{Zn}$; $\mathrm{Fe}$ vs $\mathrm{HCO}_{3} ; \mathrm{K}$ vs $\mathrm{SO}_{4}$; $\mathrm{K}$ vs $\mathrm{Mn} ; \mathrm{Mn}$ vs $\mathrm{HCO}_{3} ; \mathrm{PO}_{4}$ vs $\mathrm{Fe} ; \mathrm{PO}_{4}$ vs $\mathrm{Zn}$. $\mathrm{SO}_{4}$ vs $\mathrm{Fe} ; \mathrm{SO}_{4}$ vs $\mathrm{Fe} ; \mathrm{SO}_{4}$ vs $\mathrm{Mn} ; \mathrm{Fe}$ vs $\mathrm{Mn}$ showed positive significant correlation Table $5(\mathrm{a}, \mathrm{b})$ which indicates that the parameters were interrelated with each other and may be originated from the same source. On the contrary, the combinations of SSP vs $\mathrm{H}_{\mathrm{T}}$, Fe vs Mg showed negative significant correlation with each other. Other relationships among the ionic constituents of water were insignificant Table $5(\mathrm{a}, \mathrm{b})$. 
Table 5(a): Relationship between quality parameters of effluent $(n=26)$ collected from the major polluting areas of Gazipur industrial area in Bangladesh

\begin{tabular}{|c|c|c|c|c|c|c|}
\hline Parameters & EC & TDS & SAR & SSP & RSC & $\mathbf{H}_{\mathrm{T}}$ \\
\hline $\mathrm{pH}$ & $0.103^{\text {ns }}$ & $0.187^{\mathrm{ns}}$ & $-0.127^{\mathrm{ns}}$ & $-0.149^{\mathrm{ns}}$ & $-0.014^{\mathrm{ns}}$ & $0.124^{\mathrm{ns}}$ \\
\hline EC & & $0.197^{\mathrm{ns}}$ & $-0.170^{\mathrm{ns}}$ & $0.080^{\mathrm{ns}}$ & $0.157^{\mathrm{ns}}$ & $0.192^{\mathrm{ns}}$ \\
\hline TDS & & & $0.689 * *$ & $0.668 * *$ & $0.066^{\mathrm{ns}}$ & $-0.326^{\mathrm{ns}}$ \\
\hline SAR & & & & $0.867 * *$ & $0.218^{\mathrm{ns}}$ & $-0.417^{\mathrm{ns}}$ \\
\hline SSP & & & & & $0.174^{\mathrm{ns}}$ & $-0.508 * *$ \\
\hline RSC & & & & & & $-0.118^{\mathrm{ns}}$ \\
\hline
\end{tabular}

Legend: $* *=$ Significant at $1 \%$ level; $*=$ Significant at $5 \%$ level; ${ }^{\text {ns }}=$ Not significant; Tabulated values of $\mathrm{r}$ with $24 \mathrm{df}$ is 0.496 at $1 \%$ level of significance and 0.388 at $5 \%$ level of significance

Table 5(b): Relationship between ionic constituents of effluent $(n=26)$ collected from the major polluting areas Gazipur industrial area in Bangladesh

\begin{tabular}{|c|c|c|c|c|c|c|c|c|c|c|c|c|}
\hline $\begin{array}{l}\text { Para- } \\
\text { meters }\end{array}$ & Mg & $\mathrm{Na}$ & $\mathbf{K}$ & $\mathrm{PO}_{4}$ & $\mathrm{SO}_{4}$ & $\mathrm{Cu}$ & $\mathbf{Z n}$ & $\mathbf{F e}$ & Mn & $\mathbf{C l}$ & $\mathrm{HCO}_{3}$ & Cd \\
\hline Ca & $0.224^{\mathrm{ns}}$ & $-0.209^{\mathrm{ns}}$ & $0.071^{\mathrm{ns}}$ & $0.372^{\mathrm{ns}}$ & $0.242^{\mathrm{ns}}$ & $\mathrm{ND}^{\mathrm{ns}}$ & $0.856 * *$ & $0.480 *$ & $-0.112^{\mathrm{ns}}$ & $-0.110^{\mathrm{ns}}$ & $-0.033^{\mathrm{ns}}$ & $\mathrm{ND}^{\mathrm{ns}}$ \\
\hline Mg & & $-0.209^{\mathrm{ns}}$ & $0.206^{\mathrm{ns}}$ & $0.162^{\mathrm{ns}}$ & $-0.212^{\mathrm{ns}}$ & $\mathrm{ND}^{\mathrm{ns}}$ & $-0.218^{\mathrm{ns}}$ & $-0.801 * *$ & $0.076^{\mathrm{ns}}$ & $-0.082^{\mathrm{ns}}$ & $-0.062^{\mathrm{ns}}$ & $\mathrm{ND}^{\mathrm{ns}}$ \\
\hline $\mathrm{Na}$ & & & $-0.072^{\mathrm{ns}}$ & $-0.011^{\mathrm{ns}}$ & $0.191^{\mathrm{ns}}$ & $\mathrm{ND}^{\mathrm{ns}}$ & $0.596 * *$ & $-0.206^{\mathrm{ns}}$ & $0.0003^{\mathrm{ns}}$ & $0.220^{\mathrm{ns}}$ & $0.029^{\mathrm{ns}}$ & $\mathrm{ND}^{\mathrm{ns}}$ \\
\hline $\mathbf{K}$ & & & & $0.047^{\mathrm{ns}}$ & $0.598^{* * *}$ & $\mathrm{ND}^{\mathrm{ns}}$ & $0.063^{\mathrm{ns}}$ & $-0.344^{\mathrm{ns}}$ & $0.617^{* *}$ & $0.120^{\mathrm{ns}}$ & $0.116^{\mathrm{ns}}$ & $\mathrm{ND}^{\mathrm{ns}}$ \\
\hline $\mathrm{PO}_{4}$ & & & & & $0.057^{\mathrm{ns}}$ & $\mathrm{ND}^{\mathrm{ns}}$ & $0.803^{* *}$ & $0.388 *$ & $0.233^{\mathrm{ns}}$ & $-0.031^{\mathrm{ns}}$ & $0.266^{\mathrm{ns}}$ & $\mathrm{ND}^{\mathrm{ns}}$ \\
\hline $\mathrm{SO}_{4}$ & & & & & & $\mathrm{ND}^{\mathrm{ns}}$ & $0.864^{* *}$ & $0.443 *$ & $0.577 * *$ & $0.134^{\mathrm{ns}}$ & $0.266^{\mathrm{ns}}$ & $\mathrm{ND}^{\mathrm{ns}}$ \\
\hline $\mathrm{Cu}$ & & & & & & & $\mathrm{ND}^{\mathrm{ns}}$ & $\mathrm{ND}^{\mathrm{ns}}$ & $\mathrm{ND}^{\mathrm{ns}}$ & $\mathrm{ND}^{\mathrm{ns}}$ & $\mathrm{ND}^{\mathrm{ns}}$ & $\mathrm{ND}^{\mathrm{ns}}$ \\
\hline $\mathbf{Z n}$ & & & & & & & & $\mathrm{ND}^{\mathrm{ns}}$ & $1^{\mathrm{ns}}$ & $-0.294^{\mathrm{ns}}$ & $-0.413^{\mathrm{ns}}$ & $\mathrm{ND}^{\mathrm{ns}}$ \\
\hline $\mathbf{F e}$ & & & & & & & & & $0.801 * *$ & $-0.177^{\mathrm{ns}}$ & $0.436^{*}$ & $\mathrm{ND}^{\mathrm{ns}}$ \\
\hline Mn & & & & & & & & & & 0.721 & $0.507 * *$ & $\mathrm{ND}^{\mathrm{ns}}$ \\
\hline Cl & & & & & & & & & & & $0.272^{\mathrm{ns}}$ & $\mathrm{ND}^{\mathrm{ns}}$ \\
\hline $\mathrm{HCO}_{3}$ & & & & & & & & & & & & $\mathrm{ND}^{\mathrm{ns}}$ \\
\hline
\end{tabular}

Legend: $* *=$ Significant at $1 \%$ level; $*=$ Significant at $5 \%$ level; ${ }^{\text {ns }}=$ Not significant; Tabulated values of $\mathrm{r}$ with $24 \mathrm{df}$ is 0.496 at $1 \%$ level of significance and 0.388 at $5 \%$ level of significance.

\section{Conclusions and Recommendations}

The $\mathrm{pH}$ of effluent samples ranged from 6.05 to 7.28 indicating all the samples were almost neutral. The EC of all collected effluent samples were within the range of 181 to $1995 \mu \mathrm{S} \mathrm{cm}^{-1}$ indicating low to high value which is harmful for irrigation. The DO value were within the range of 0.30 to $1.5 \mathrm{mg} \mathrm{L}^{-1}$ indicating that aquatic life is in under stress but in case of irrigation it is not essential. The TDS value ranged from 465 to $1587 \mathrm{mg} \mathrm{L}^{-1}$ indicating effluent as fresh to brackish in which $58 \%$ of effluent samples were rated as fresh water $(<1000 \mathrm{mg} \mathrm{L}$ $\left.{ }^{1}\right)$. The anion chemistry in the Gazipur industrial area was dominated by $\mathrm{HCO}_{3}$ and $\mathrm{Cl}$ which contributed 55 and $44 \%$ of the total anionic balance, respectively. Results obtained from the study reflects that effluent collected from Gazipur industrial area were dominated by $\mathrm{Na}, \mathrm{Mg}, \mathrm{Ca}$, and $\mathrm{K}$, which contributed 58, 17, 16 and $9 \%$ of the total cationic balance, respectively. Among the studied trace metals ( $\mathrm{Fe}, \mathrm{Zn}, \mathrm{Cu}, \mathrm{Pb}, \mathrm{Cd}$ and $\mathrm{Mn}$ ), all of the effluent samples were less than the maximum recommended concentration indicating them not problematic for long term irrigation purposes except two samples one for $\mathrm{Mn}$ and another for $\mathrm{Cu}$. The quality assessment showed high values of $\mathrm{HCO}_{3}\left(14.00 \mathrm{me} \mathrm{L}^{-1}\right)$,
$\mathrm{Cl}$ (25.77 $\left.\mathrm{me} \mathrm{L} \mathrm{L}^{-1}\right), \mathrm{Mn}\left(0.286 \mathrm{mg} \mathrm{L}^{-1}\right)$ and $\mathrm{Cu}(4.19 \mathrm{mg}$ $\mathrm{L}^{-1}$ ) in a number of samples, which make them unsafe for irrigation purpose. The computed SAR of all effluent samples were ranged from 2.66 to 45.9 with a mean value of 12.60. Among the 26 effluent samples, 17 effluents samples categorized as excellent, 6 samples were graded as fair and the rest 3 samples were graded as poor category for irrigation purpose. Considering SSP for 26 effluent samples, 23 effluent samples were graded as doubtful and the rest 3 samples were graded as permissible for irrigating agricultural crops. The computed RSC varied from -0.59 to 16 me $\mathrm{L}^{-1}$ with a mean value of $4.84 \mathrm{me} \mathrm{L}^{-1}$ and among the 26 effluent samples, 19 samples were found in unsuitable class (> 2.50), 4 samples were found in suitable class $(<1.25)$ and the rest 3 sample were in marginal class (1.25-2.50). As regards to hardness, out of 26 effluent samples, 11 effluent samples were graded as hard and the rest 15 samples were graded as very hard. High values of hardness of some samples collected from Gazipur industrial areas restricted the suitability of water in this area for agriculture and demands suitable water management as well as proper treatment. 


\section{Acknowledgement}

The authors acknowledge all officials and laboratory staffs of the Department of ESRM, MBSTU, Tangail

\section{References}

Agarwal, R.R.; Yadav, J.P. and Gupta, R.N. 1982. Saline and Alkali Soils of India, Indian Council of Agricultural Research, New Delhi, India. pp. 223228.

APHA (American Public Health Association). 1995. Standard Methods for the Examination of Water and Waste Water, $19^{\text {th }}$ Edition, Washington DC, USA. 1019 p.

Appelo, C.A.J. and Postma, D. 1993. Geochemistry, Groundwater and Pollution,. A Balkema Publisher, USA. $536 \mathrm{p}$

Ayers, R.S. and Westcot, D.W. 1985. Water quality for agriculture. FAO Irrigation and Drainage Paper, 29: 4096.

Berner, E.K. and Berner, R.A. 1987. The Global Water Cycle: Geo-chemistry and Environment,. Prentice Hall Inc., Englewood Cliffs, New Jersey, USA. $387 \mathrm{pp}$.

BIS (Bureau of Indian Standards). 1991. Indian Standards Institution-Indian Standards specification for drinking water. IS: 10500, New Delhi, India.

CNN (Cable News Network) Report. 2012. 152 Industries wreaking havoc in Turag River, Saver, Dhaka, Bangladesh.Date-15/09/2010.

www.webcrawler.com

Domenico, P.A. and Schwartz, F.W. 1990. Physical and Chemical Hydrologeology,. $2^{\text {nd }}$ Edition, Wiley, New York. 528p

Doneen L.D. 1964. Notes on Water Quality in Agriculture. Water Science and Engineering Paper 4001, Department of Water Sciences and Engineering, University of California, Davis.

Freeze, A.R. and Cherry, J.0A. 1979. Groundwater,. Prentice Hall Inc., Englewood Cliffs, New Jersey, USA. 84p

Ghosh, A.B.; Bajaj, J.C.; Hasan, R. and Singh, D. 1983. Soil and Water Testing Methods, A Laboratory Manual, Division of Soil Science and Agricultural Chemistry, IARI, New Delhi, India pp. 1-48.

Gibeault, V.A. and Cockerham, S.T. 1985. Turfgrass, Water Conservation. ANR Publications, University of California, USA. 155p

Huq, M. and Wheeler D. 1993. Pollution reduction without formal Rgulation Evidence from Bangladesh. In: Environment department divisional working paper, pp. 993-39.

Jaquet, J.M. ; Davaud, E. ; Rapin, F. and Vernet, J.P. 1982. Concept and associated statistical methodology in geochemical study of lake sediments. Hydrobiologia, 91: 139-146

Karanth, K. R. 1994. Ground Water Assessment Development and Management. Tata McGrawHill Publishing Company Ltd., New Delhi, India. Pp:248-250

Meade J.W. 1989. Aquaculture Management. CBS Publishers \& Distributors, New Delhi, India. 9 pp

Mohammad, G.; Poursafa, P.; Amin, M.M.; Ziarati, M.; Ghoddousi, H.; Momeni, S.A. and Rezaei, A.H. and Department of Agricultural Chemistry, BAU, Mymensingh for their best cooperation and laboratory supports during the research work.

2011. Environmental Impact Assessment of the Industrial Estate Development Plan with the Geographical Information System and Matrix Methods. Hindawi Publishing Corporation, 2012: 407162.

Raghunath, H.M. 1987. Ground Water. Wiley Eastern Ltd. Delhi, India.

Rao, B.K.; Panchaksharjah, S.; Patil, B.N.; Narayana, A. and Kaiker, D.L.S. 1982. Chemical composition of irrigation waters from selected parts of Bijpur district, Karnataka. Mysore Journal of Agricultural Science, 16: 426-432.

Rashid, P. 2012. http://www.fotovisura.com/user/Probal/ view/pollution-in-bangladesh

Richards, L.A. 1968. Diagnosis and Improvement of Saline and Alkaline Soils,. Agricultural Handbook 60, USDA, Oxford and IBH Publishing Company Ltd., New Delhi, India. pp. 98-99

Saleh, A.; Al-Ruwaih, F. and Shehata, M. 1999. Hydrogeochemical processes operating within the main aquifers of Kuwait. Journal of Arid Environment, 42: 195-209.

Sawyer, C.N. and McCarty, P.L. 1967. Chemistry for Sanitary Engineers,. $2^{\text {nd }}$ Edition, McGraw Hill, New York, USA. 518p

Sincero, A.P. and Sincero, G.A. 2004. Environmental Engineering: A Design Approach,. Prentice-Hall of India Private Limited, New Delhi, India. pp. 120-122

Singh, A.K.; Mahato, M.K.; Neogi, B. and Singh, K.K. 2010. Quality assessment of mine water in the Raniganj coalfield area, India. Mine Water Environment, 29: 248-262.

Todd, D.K. 1980. Groundwater Hydrology. $2^{\text {nd }}$ Edition, John Wiley and Sons Inc., New York, USA. 304p

WHO (World Health Organization). 2008. Guidelines for drinking-water quality. In: incorporating $1^{\text {st }}$ and $2^{\text {nd }}$ addenda, 1:515 $\mathrm{p}$.

Wilcox, L.V. 1955. Classification and Use of Irrigation Water, Circular No. 969, Washington, USA. 19 pp. 